\title{
Isolation of Leptospira spp. from a man living in a rural area of the Municipality of Cruz Alta, RS, Brazil
}

Isolamento de Leptospira spp. em um morador da zona rural do Município de Cruz Alta, RS, Brasil

\author{
Felipe Jorge da Silva ${ }^{I^{*}}$ Glaucenyra Cecília Pinheiro Silva ${ }^{\mathrm{I}}$ Sylvia Grune Loffler ${ }^{\text {II }}$ \\ Bibiana BrihuegaII Luis Ernesto Samartino"II Miguel Frederico Fernandez Alarcon ${ }^{\text {III }}$ \\ Carlos Eduardo Pereira dos Santos ${ }^{\mathrm{IV}}$ Luis Antonio Mathias ${ }^{\mathrm{I}}$
}

\section{ABSTRACT}

The aim of this study was to describe the isolation of a pathogenic strain of Leptospira interrogans from the urine sample of a male human living in the rural area of the County of Cruz Alta, Rio Grande do Sul. An aliquot of each urine sample was sown in a Fletcher and Ellinghausen - McCullough - Johnson - Harris (EMJH) media. Samples in which there was growth of spirochetes were sent to the Leptospirosis Laboratory of the Institute of Pathobiology in the National Institute of Agricultural Technology, Buenos Aires, Argentina and were typified by the Multiple Locus of Variable Number Tandem Repeat technique (MLVA). Leptospira interrogans serovar Copenhageni strain Fiocruz L1-130 was isolated, and this is a very important finding that serves as a warning to characterize risk situation of leptospirosis epidemic by a pathogenic strain. Health professionals need to be more committed to the primary health care in Brazil and routinely apply actions of preventive medicine in rural communities in order to get success in the control of leptospirosis and other important zoonoses.

Key words: human leptospirosis, Isolation, MLVA, Farm, Brazil.

\section{RESUMO}

O objetivo do presente estudo foi descrever um caso de isolamento de espécie patogênica de Leptospira interrogans em amostra de urina de um humano morador da zona rural do Município de Cruz Alta, Estado do Rio Grande do Sul. De cada amostra de urina, uma alíquota foi semeada nos meios Fletcher e Ellinghausen - McCullough - Johnson - Harris (EMJH). As amostras, nas quais houve crescimento de espiroquetas, foram encaminhadas para o Laboratório de Leptospirose do Instituto de Patobiologia do Instituto Nacional de Tecnologia Agropecuária,
Buenos Aires, Argentina e foram tipificadas pela técnica Multiple Locus of Variable Number Tandem Repeat (MLVA). De um residente do sexo masculino da área rural do município de Cruz Alta, foi isolada Leptospira interrogans sorovariedade Copenhageni cepa Fiocruz L1-130, uma descoberta muito importante e que serve como um alerta por caracterizar uma situação de risco de epidemia de leptospirose por uma cepa patogênica. Os profissionais de saúde precisam ser mais comprometidos com a atenção primária à saúde no Brasil e rotineiramente aplicar ações de medicina preventiva nas comunidades rurais, a fim de obter sucesso no controle da leptospirose e de outras importantes zoonoses.

Palavras-chave: leptospirose humana, isolamento, MLVA, propriedade rural, Brasil.

\section{INTRODUCTION}

Although leptospirosis is known as an occupational disease in most countries, in Brazil it is acquired through contact with water contaminated by urine of infected animals, and its epidemiological characteristic is associated with socioeconomic conditions (ROMERO et al., 2003). In addition to this description, epidemiological characteristics and risk factors for leptospirosis in rural areas are different from those in urban areas. In rural areas the transmission occurs more frequently because of deficiency of good sanitary practices in animal handling.

\footnotetext{
IDepartamento de Medicina Veterinária Preventiva e Reprodução Animal, Faculdade de Ciências Agrárias e Veterinárias (FCAV), Universidade Estadual Paulista (UNESP), Via de Acesso Professor Paulo Donato Castellane s/n, 14884-900, Jaboticabal, SP, Brasil. E-mail: fjsepi@gmail.com.*Corresponding author.

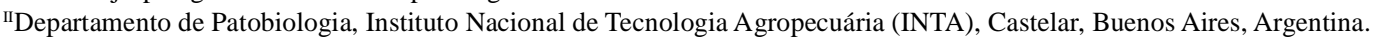

IIIDepartamento de Fisiologia Animal, FCAV, UNESP, Jaboticabal, SP, Brasil.

${ }^{\text {IV }}$ Departamento de Clínica Médica Veterinária, Faculdade de Agronomia, Medicina Veterinária e Zootecnia (FAMEVZ), Universidade Federal de Mato Grosso (UFMT), Cuiabá, MT, Brasil. 
Surveys conducted by KO et al. (2007) and by ATHANAZIO et al. (2008) described the pathogenesis and the pathological changes caused by Leptospira interrogans serovar Copenhageni strain Fiocruz L1-130 (KO et al., 1999 in the kidneys of rats.

By reporting the isolation of Leptospira interrogans serovars Canicola and Copenhageni from cattle urine in the state of Paraná, ZACARIAS et al. (2008) affirmed that rats are the common maintenance hosts of serovar Copenhageni. They also said that cattle can represent a risk for human leptospirosis by the excretion of highly pathogenic serovars such as Copenhageni.

In farmed deer in New Zealand, SUBHARAT et al. (2010) claimed that livestock farming plays an important role as occupational risk factor for human leptospirosis and stated that farmed deer is one of the contributing factors. In a sheep slaughterhouse in New Zealand, DORJEE et al. (2008) demonstrated the presence of a definite risk of occupational exposure of meat workers to serovars of Leptospira spp. In the same way, DORJEE et al. (2011) provided evidence that processing of sheep carcasses exposed meat workers regularly to infective leptospires.

There are lack of studies about the role of human being as host of Leptospira spp. in rural areas of Brazil, and specially, there are very few studies about the epidemiological chain of leptospirosis in our conditions. Thus, the aim of this study was to describe an isolation of Leptospira interrogans serovar Copenhageni strain Fiocruz L1-130 from the urine sample of a human living in the rural area of the Municipality of Cruz Alta, Rio Grande do Sul State.

\section{METHODOLOGY}

The farm where the investigation was carried out is located in the rural area of the municipality of Cruz Alta, region of southern fields in Rio Grande do Sul State.

For urine collection, the volunteer is instructed to perform the prior procedure of disinfection and then collect, in appropriate sterile bottle, the first morning urine, discarding the first jet. Then the urine collected in the bottle was transferred to sterile and disposable Falcon tubes.

Soon after, an aliquot of urine from the tube was taken with the aid of sterile disposable syringe. A $0.22 \mu \mathrm{m}$ filter was coupled to the syringe tip, and near the Bunsen burner tree drops of filtered urine were simultaneously transferred to a sterile tube with liquid culture media Ellinghausen-McCulloughJohnson-Harris (EMJH) without antimicrobials and three drops were transferred to a sterile tube with semisolid media Fletcher culture without antimicrobials (THIERMANN, 1980; ELLIS et al., 1982). Tubes were placed in closed containers, protected from light, at room temperature and weekly evaluated until transport to the Laboratório de Diagnóstico de Brucelose e Leptospirose, Departamento de Medicina Veterinária Preventiva e Reprodução Animal, Faculdade de Ciências Agrárias e Veterinárias de Jaboticabal (FCAV-Unesp), in which the tubes were incubated in a bacteriological incubator chamber (BOD) at $28^{\circ} \mathrm{C}$.

No volunteer showed any clinical alteration indicative of leptospirosis. In this regard, the clinical condition was not a sampling criterion, since it is known that an individual may be infected but not show any clinical symptoms.

All volunteers had their identities kept in complete confidence. For the exams, each person, of legal age or not, signed a term of free and informed consent.

Cultures were evaluated weekly for a period ranging from eight to sixteen weeks (THIERMANN, 1980; ELLIS et al., 1982). When the Leptospira spp. growth ring was observed in Fletcher medium, the culture was subcultured into EMJH without antimicrobials (FAINE et al., 1999). The tubes that showed contamination in the weekly evaluation were discarded.

From the EMJH medium with growth of Leptospira spp. and uncontaminated an aliquot was removed for observation under dark field microscopy. To confirm growth of Leptospira spp., $1 \mathrm{~mL}$ of Fletcher culture medium corresponding was removed, from the growth ring area, and $1 \mathrm{~mL}$ of the EMJH culture medium corresponding was also removed and placed in $1.5 \mathrm{~mL}$ sterile disposable eppendorf tubes for transport to the leptospirosis laboratory (OIE Reference laboratory for leptospirosis) Institute of Pathobiology, Center for Research in Veterinary and Agricultural Sciences, National Institute of Agricultural Technology (INTA), Buenos Aires, Argentina. In this lab, isolated leptospires were typified by the Multiple Locus of Variable Number Tandem Repeat technique (MLVA) (PAVAN et al., 2011).

The reference and the isolated strains were grown in Fletcher medium (Difco Laboratories) at $28^{\circ} \mathrm{C}$. From the DNA formers used in the typing procedures MLVA performed with the primers described by MAJED et al. (2005) and SALAÜN et al. (2006), $100 \mu \mathrm{L}$ from the culture sample were incubated at $100^{\circ} \mathrm{C}$ during 10 minutes. The MLVA typing was done using two sets of oligonucleotides 
specific for the species Leptospira interrogans, $\boldsymbol{L}$. borgpetersenii and L. kirschneri. The loci VNTR4, VNTR7, VNTR9, VNTR10, VNTR19, VNTR23 and VNTR31 were used to discriminate $L$. interrogans strains (MAJED et al., 2005) and VNTR4, VNTR7, VNTR10, LB4 and LB5 were used to L. kirschneri, L. borgpetersenii and $\boldsymbol{L}$. interrogans (SALAÜN et al., 2006). The final volume $(50 \mu \mathrm{L})$ of each reaction mixture containing RCP buffer (20mM Tris-HCL, $\mathrm{pH} 8.4,50 \mathrm{mM}$ of $\mathrm{KCl}), 200 \mu \mathrm{m}$ of deoxinucleoside triphosphates, $2 \mu \mathrm{m}$ of each corresponding primer, $2 \mathrm{mM}$ of $\mathrm{MgCl} 2,1.25 \mathrm{U}$ of Taq DNA polymerase (Invitrogen) and 5uL of DNA model. PCRs were performed in a thermocycler as follows: $94^{\circ} \mathrm{C}$ for $5 \mathrm{~min}$, followed by 35 cycles of denaturation at $94^{\circ} \mathrm{C}$ for $30 \mathrm{~s}$, hybridization at $55^{\circ} \mathrm{C}$ for $30 \mathrm{~s}$ and extension at $72^{\circ} \mathrm{C}$ for $90 \mathrm{~s}$, with a final cycle of $72^{\circ} \mathrm{C}$ for $10 \mathrm{~min}$. The amplified samples $(15 \mu \mathrm{L})$ were revealed by electrophoresis on a $2 \%$ agarose gel in TAE buffer (40mM Tris - acetate, $1 \mathrm{mMEDTA}$ ) with $0.2 \mathrm{uLug} \mathrm{ml}{ }^{-1}$ of ethidium bromide at $100 \mathrm{~V}$ for $50 \mathrm{~min}$. Amplified DNA bands were visualized after exposure to UV light (Uvi TEC transiluminator BTS-20.M). The size of amplified were estimated using CienMarker (Biodinâmica) and 2010a GelAnalyzer program. To calculate the number of repeat copies, the following formula was used: Number of repeat $(\mathrm{pb})=$ [fragment size (pb) - flanking regions (bp)] size / Size of repeat $(\mathrm{pb})$. The numbers of repeat copies were rounded to whole numbers. If the number of copies were less than one, it was rounded to zero.

The genotypes obtained were used to mount two phylogenetic trees with the assistance of Mega Software 5.05 program (TAMURA et al., 2011). The tree was constructed by the neighborjoining method, using seven locos markers for strains of L. interrogans.

\section{RESULTS AND DISCUSSION}

Leptospira interrogans serovar Copenhageni strain Fiocruz L1-130 (Figure 1) was isolated from a human male living in the rural area of County of Cruz Alta.

This study was able to isolate Leptospira interrogans serovar Copenhageni strain Fiocruz L1-130 (KO et al., 1999), and surveys conducted by $\mathrm{KO}$ et al. (2007) and by ATHANAZIO et al. (2008) emphasizes the important role of rodents in the epidemiological chain of leptospirosis, indicating their condition as reservoir of this strain to humans.

It is a very valuable discovery, since it proves that humans are one of the links in the epidemiological chain of leptospirosis in rural areas, as well as wild and domestic animals. It serves to warn the health professionals to characterize risk situation of leptospirosis epidemic by a pathogenic strain.

There are studies that reiterate the large diversity of hosts of Leptospira spp. in rural areas. SUBHARAT et al. (2010) claimed that livestock farming represents an important role as occupational risk factor for human leptospirosis. This survey also emphasizes that farmed deer is one of the contributing factors, showing the role of wild animals as reservoirs of Leptospira spp. DORJEE et al. (2008) and DORJEE et al. (2011) put leptospirosis as an alarming public health disease when describing the meat workers as professionals who are constantly exposed to infective leptospires.

In Brazil, ZACARIAS et al. (2008) reinforces the role of rats as reservoir of serovar Copenhageni and also put the urine of infected cattle as a risk for human leptospirosis.

Poor sanitary practices are widely observed in rural properties in Rio Grande do Sul State and all through Brazil. Such pratices include rubbish and organic garbage accumulation, lack of sanitation on animal feeders and drinkers, poor packaging of feed and neglect water quality. They promote proliferation of rats, other synanthropic organisms and wild animals free living, a condition that facilitates the transmission of the etiologic agent from the source of infection to a susceptible host.

Some important measures to control leptospirosis are: rodent control through antirodent actions, elimination of the excess of standing water in the environment, isolation and treatment of sick animals, detection and treatment of healthy carriers and systematic animals immunization. On synanthropic and wild reservoirs, sanitation and antirodent measures should be taken, such as adequate garbage disposal, proper storage of food for human and animal use, like avoiding storage of debris that serves as shelter (BRASIL, 2010).

\section{CONCLUSION}

A strain identified as Leptospira interrogans serovar Copenhageni strain Fiocruz L1-130 was isolated from a human male living in the rural area of County of Cruz Alta, Rio Grande do Sul State, Brazil. Humans are one of the links in the epidemiological chain of leptospirosis in rural areas and can act as hosts to the pathogenic strains of the agent, a condition that serves as a warning to characterize a risk of leptospirosis epidemic. Health 


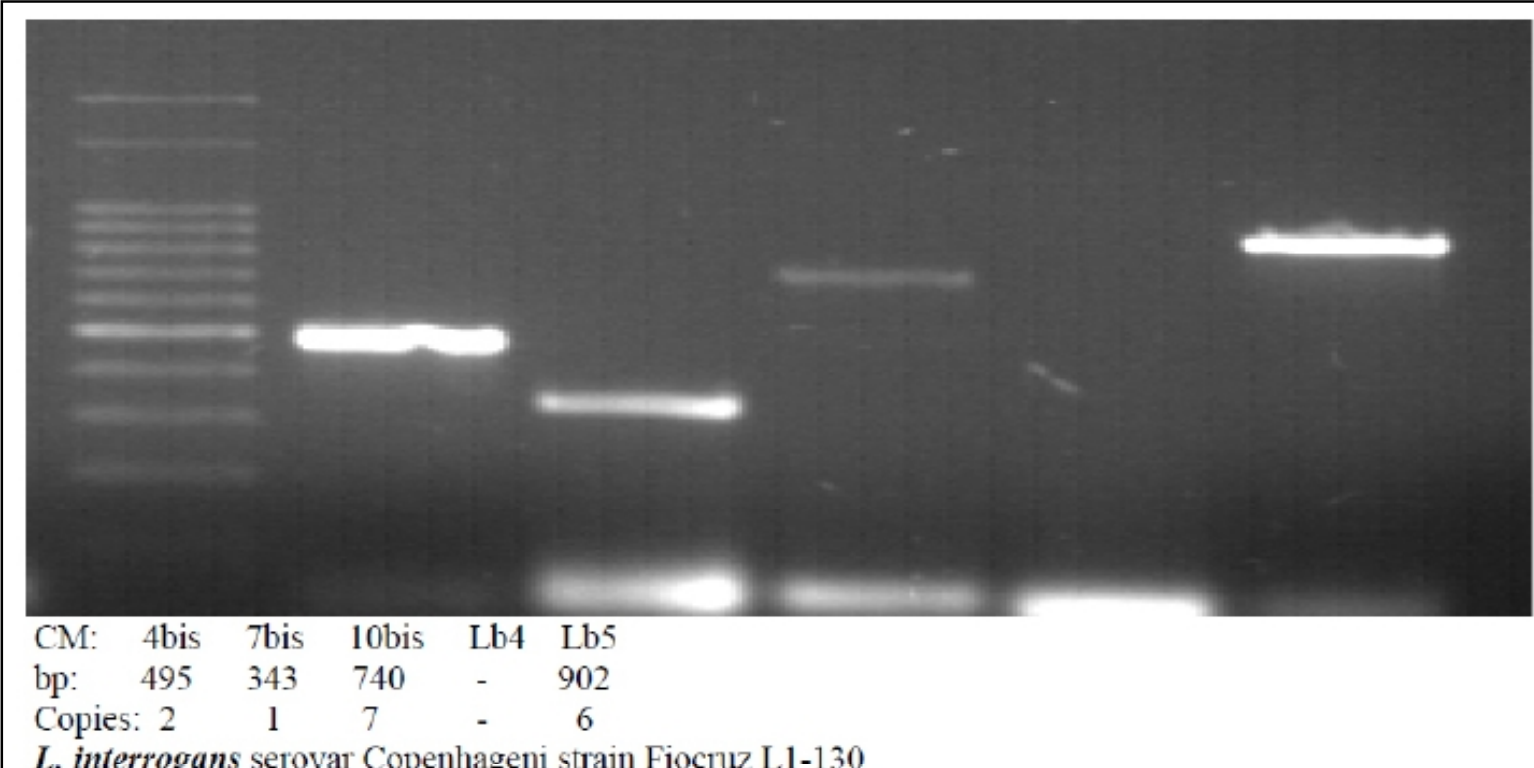

\section{L. interrogans serovar Copenhageni strain Fiocruz L1-130}

Figure 1 - Gel with recognized genotipes identifying the Leptospira interrogans serovar Copenhageni strain Fiocruz L1-130 isolated from a male human in rural area of County of Cruz Alta, Rio Grande do Sul State, Brazil. 2013.

professionals need to be more committed to the primary health care in Brazil and routinely apply actions of preventive medicine in rural communities in order to get success in the control of leptospirosis and other important zoonoses.

\section{BIOETHICS AND BIOSSECURITY COMMITTEE APPROVAL}

For this paper, authorization was granted by Instituto Brasileiro do Meio Ambiente e dos Recursos Naturais Renováveis (IBAMA) to work with free-living wild animals, which grant number is: $26185-1$ (date of issue: $02 / 07 / 2011$ at $16: 18 \mathrm{~h}$ ). It has also been granted permission from the Comissão de Ética no Uso de Animais (CEUA) to work with free-living and domestic animals, whose protocol number is: 027958/10 (date of issue: 12/20/2010). This document still places that the present research is in accordance with ethical principles in animal experimentation adopted by the Colégio Brasileiro de Experimentação (COBEA). Finally, authorization was granted by the Comissão Nacional de Ética em Pesquisa (CONEP) to work with humans, and the process number is 4870 .

\section{ACKNOWLEDGEMENTS}

Universidade Estadual Paulista, Campus de Jaboticabal (FCAV-Unesp); Fundação de Amparo à Pesquisa do Estado de São Paulo (FAPESP)

\section{REFERENCES}

ATHANAZIO, D.A. et al. Rattus norvegicus as a model for persistent colonization by pathogenic Leptospira interrogans. Acta Tropica, Amsterdam, v.105, p.176-180, 2008. Available from: <http://
www.sciencedirect.com/science/article/pii/S0001706X0700263X>. Accessed: jul. 21, 2014. doi: 10.1016/j.actatropica.2007.10.012.

BRASIL. Ministério da Saúde. Doenças infecciosas e parasitárias: guia de bolso. 8.ed. Brasília: Secretaria de Vigilância em Saúde, 2010. p. $274-282$.

DORJEE, S. et al. Prevalence of pathogenic Leptospira spp. in sheep in a sheep-only abattoir in New Zealand. New Zealand Veterinary Journal, Palmerston North, v.56, p.164-170, 2008. Available from: <http://www.tandfonline.com/doi/abs/10.1080/0 0480169.2008.36829\#.U80AOPldVJI>. Accessed: jul. 21, 2014. doi: 10.1080/00480169.2008.36829.

DORJEE, S. et al. Assessment of occupational exposure to leptospirosis in a sheep-only abattoir. Epidemiology and Infection, Cambridge, v.139, p.797-806, 2011. Available from: <http://www.tandfonline. com/doi/abs/10.1080/00480169.2008.36829\#.U80AOPldVJI>. Accessed: jul. 21, 2014. doi: 10.1017/S0950268810002049.

ELLIS, W.A. Bovine leptospirosis: serological findings in aborting cows. Veterinary Record, London, v.110, p.178-180, 1982. Available from: <http://www.tandfonline.com/doi/abs/10.1080/0 0480169.2008.36829\#.U80AOPldVJI>. Accessed: jul. 21, 2014. doi: $10.1136 /$ vr.110.8.178.

FAINE, S. Leptospira and leptospirosis. 2.ed. Melbourne: MedSci, 1999. 272p.

KO, A.I. et al. Urban epidemic of severe leptospirosis in Brazil. Lancet, London, v.354, p.820-825, 1999. Available from: <http:// www.tandfonline.com/doi/abs/10.1080/00480169.2008.36829\#. U80AOPldVJI>. Accessed: jul. 21, 2014. doi: 10.1016/S01406736(99)80012-9.

KO, A.I. et al. Morphological alterations in the kidney of rats with natural and experimental leptospiral infection. Journal of

Ciência Rural, v.45, n.1, jan, 2015. 
Comparative Pathology, Liverpool, v.137, p.231-238, 2007. Available from: <http://www.sciencedirect.com/science/article/ pii/S0021997507001338>. Accessed: jul. 21, 2014. doi: 10.1016/j. jcpa.2007.08.001.

MAJED, Z. et al. Identification of variable-number tandem-repeat loci in Leptospira interrogans sensu stricto. Journal of Clinical Microbiology, Washington, v.43, p.539-545, 2005. Available from: <http://www.tandfonline.com/doi/abs/10.1080/00480169.20 08.36829\#.U80AOPldVJI>. Accessed: jul. 21, 2014. doi: 0.1128/ JCM.43.2.539-545.2005.

PAVAN, M.E. et al. Genotyping of Leptospira interrogans strains from Argentina by Multiple-Locus Variable-number tandem repeat Analysis (MLVA). Comparative Immunology, Microbiology and Infectious Diseases, Davis, v.34, p.135-141, 2011. Available from: <http://www.tandfonline.com/doi/abs/10.1080/0048016 9.2008.36829\#.U80AOPldVJI>. Accessed: jul. 21, 2014. doi: 10.1016/j.cimid.2010.06.002.

ROMERO, E.C. et al. Human leptospirosis: a twenty-nineyear serological study in São Paulo, Brazil. Revista do Instituto de Medicina Tropical, São Paulo, v.45, n.5, p.245248, 2003. Available from: <http://dx.doi.org/10.1590/S003646652003000500002>. Accessed: jul. 21, 2014. doi: 10.1590/ S0036-46652003000500002.

SALAÜN, L. et al. Application of multilocus variablenumber tandem-repeat analysis for molecular typing of the agent of leptospirosis. Journal of Clinical Microbiology,
Washington, v.44, p.3954-3962, 2006. Available from: <http:// www.tandfonline.com/doi/abs/10.1080/00480169.2008.368 29\#.U80AOPldVJI>. Accessed: jul. 21, 2014. doi: 10.1128/ JCM.00336-06.

SUBHARAT, S. Epidemiology, diagnosis and vaccination control of leptospirosis in farmed deer in New Zealand. 2010. 271f. Thesis (Doctor of Philosophy in Veterinary Clinical Science) - Massey University Palmerston North, New Zealand.

TAMURA, K. et al. MEGA 5: molecular evolutionary genetics analysis using maximum likelihood, evolutionary distance, and maximum parsimony methods. Molecular Biology and Evolution, Oxford, v.28, p.2731-2739, 2011. Available from: <http://www.tandfonline.com/doi/abs/10.1080/00480169.2008. 36829\#.U80AOPIdVJI>. Accessed: jul. 21, 2014. doi: 10.1093/ molbev/msr121.

THIERmanN, A.B. Canine leptospirosis in Detroit. American Journal of Veterinary Research, Chicago, v.41, n.10, p.16591661, 1980. Available from: <http://www.tandfonline.com/doi/ab s/10.1080/00480169.2008.36829\#.U80AOPldVJI>. Accessed: jul. 21, 2014. doi: 10.1080/00480169.2008.36829.

ZACARIAS, F.G.S. et al. Isolation of leptospira Serovars Canicola and Copenhageni from cattle urine in the state of Paraná, Brazil. Brazilian Journal of Microbiology, São Paulo, v.39, n.4, p.484488, 2008. Available from: <http://dx.doi.org/10.1590/S151783822008000400028>. Accessed: jul. 21, 2014. doi: 10.1590/ S1517-83822008000400028. 